\title{
Herbal composition of Cinnamomum cassia, Pinus densiflora, Curcuma longa and Glycyrrhiza glabra prevents atherosclerosis by upregulating p27 (Kip1) expression
}

\author{
Jung-Jin Lee ${ }^{1}$, Ji-Hye Lee', Won-Kyung Cho' ${ }^{1}$ Joo-Hui Han² and Jin Yeul Ma*
}

\begin{abstract}
Background: Kiom-18 is a novel composition of Cinnamomum cassia, Pinus densiflora, Curcuma longa and Glycyrrhiza glabra. Curcuma longa and Glycyrrhiza glabra, which are traditional medicines in Asia, have been reported to demonstrate preventive effects against atherosclerosis; however, they have not yet been developed into functional atherosclerosis treatments. We therefore studied the anti-atherosclerotic effects and possible molecular mechanisms of Kiom-18 using vascular smooth muscle cells (VSMCs).

Methods: To assess the anti-proliferative effect of Kiom-18 in vitro, we performed thymidine incorporation, cell cycle progression, immunoblotting and immunofluorescence assays in VSMCs stimulated by platelet derived-growth factor (PDGF)-BB. In addition, we used LDLr knockout mice to identify the effects of Kiom-18 as a preliminary result in an atherosclerosis animal model.

Results: Kiom-18 inhibited platelet-derived growth factor (PDGF)-BB-stimulated-VSMC proliferation and DNA synthesis. Additionally, Kiom-18 arrested the cell cycle transition of $G_{0} / G_{1}$ stimulated by PDGF-BB and its cell cycle-related proteins. Correspondingly, the level of p2 $7^{\text {kip } 1}$ expression was upregulated in the presence of the Kiom-18 extract. Moreover, in an atherosclerosis animal model of LDLr knockout mice, Kiom-18 extract showed a preventive effect for the formation of atherosclerotic plaque and suppressed body weight, fat weight, food treatment efficiency, neutrophil count, and triglyceride level.
\end{abstract}

Conclusions: These results indicate that Kiom-18 exerts anti-atherosclerotic effects by inhibiting VSMC proliferation via $G_{0} / G_{1}$ arrest, which upregulates p27 ${ }^{\text {Kip } 1}$ expression.

Keywords: Anti-atherosclerotic activity, Vascular smooth muscle cell, Cell cycle, Cyclin-dependent kinase inhibitor, Kiom-18

\section{Background}

The proliferation of vascular smooth muscle cells (VSMCs) is one of the most important pathogenic mechanisms in the formation of atherosclerotic plaque $[1,2]$. This abnormal proliferation contributes to cardiovascular disease, including atherosclerosis, balloon angioplasty-induced restenosis, and hypertension [2-5]. VSMC proliferation is regulated by the cell cycle, which is a complex and stepwise

\footnotetext{
* Correspondence: jyma@kiom.re.kr

'Korean Medicine (KM) Application Center, Korea Institute of Oriental Medicine, Daegu 701-300, Republic of Korea

Full list of author information is available at the end of the article
}

process, via the regulation of cyclin-dependent kinase (CDK)/cyclin complexes and CDK inhibitors (CKIs) [6, 7]. Specific phases in cell cycle progression are regulated by the formation of a complex with the catalytic subunit of CDKs $[8,9]$. Upon stimulation, the $\mathrm{G}_{1}$ phase of quiescent VSMCs leads to the $\mathrm{S}$ phase via the regulation of CDK2/ cyclin E1 and CDK4/cyclin D1 complexes in addition to CDK inhibitors such as p21, p53, p27 and p16. This progression results in the hyper-phosphorylation of retinoblastoma protein $(\mathrm{Rb})$ and the dissociation of transcription factor E2F, which initiates the transcription of genes required for DNA synthesis $[10,11]$. In previous studies, 
upregulating p21 and p27 expression has been shown to arrest cells at the $G_{0} / G_{1}$ phase to prevent the development of atherosclerosis [12-15].

The topic of this study, Kiom-18, is a novel composition of four herbal components: Chinese cinnamon (Cinnamomum cassia), Japanese red pine (Pinus densiflora), turmeric (Curcuma longa) and licorice (Glycyrrhiza glabra). These four herbal components of Kiom-18 have been previously reported to exhibit beneficial in vitro and in vivo effects as traditional medicines. C. cassia, a traditional Chinese herbal medicine, has been used in herbal formulas, such as Ge-Gen-Tang (Kakkon-to) and Sini Tang, to manage various diseases, including colds, congestion, fever, heart failure and myocardial infarction [16-21]. $P$. densiflora, a plant that is common throughout Asia, has traditionally been used as a tea, food ingredient, or folk medicine $[22,23]$. C. longa has been widely used as a traditional medicine in Southeast Asia, and curcumin is its major active component [24]. In addition, $C$. longa, Japanese alder (Alnus japonica) and Massa Medicata Fermentata (medicated leaven) make up gambigyeongsinhwan (4), which has been used to treat obesity in local Korean clinics; the mechanism of its anti-obesity effect has recently been established [25]. Traditionally, G. glabra, a medicinal herb cultivated in several regions of the world, has been used in the treatment of kidney stones, hepatitis $C$, and cough and stomach ailments [26, 27]. In a recent report, $C$. cassia was demonstrated to have anti-cancer effects, via the bioactive compound cinnamaldehyde isolated from the stem bark; anti-diabetic effects, due to the inhibition of fibronectin, monocyte chemoattractant protein- 1 and interleukin- 6 by its active components, antiosteoporosis effects, as found in Jasin-hwan-gagambang (BHH10), a formula that includes $C$. cassia, and antiinflammatory effects, through the blockage of NF-kB by cinnamaldehyde [28-32]. P. densiflora exerts anti-oxidant activity in a variety of applications, anti-cancer activity in human oral squamous cell carcinoma using an oil formulation of $P$. densiflora leaf and hepatoprotective activity by regulating lipid accumulation and oxidative stress in the liver [33-35]. Recently, C. longa and G. glabra have been reported to have beneficial effects. $C$. longa may be useful as a natural supplement for the treatment of metabolic syndrome: it has anti-diabetic effects by inhibiting angiotensin converting enzyme, and an ethanolic extract exerts a neuroprotective effect in the hippocampus [36, 37]. Moreover, G. glabra has hepatoprotective effects in combination with glycyrrhizin and silymarin, which are metabolites of G. glabra and milk thistle (Silybum marianum), respectively, and anti-tubercular effects for its extract that includes active compounds [38, 39]. Among these individual components of Kiom-18, C. longa and G. glabra have been reported in many studies to prevent atherosclerosis by the suppression of low-density lipoprotein (LDL) oxidation; however, to date, they have not been developed as supplemental foods for the treatment of atherosclerosis [40-45]. Therefore, we studied the anti-atherosclerotic effects of a novel composition including C. longa and $G$. glabra for its potential use in supplementary foods. We also examined the effects on VSMC proliferation and the molecular mechanism of its anti-proliferative action.

\section{Methods}

\section{Materials and reagents}

The bark from Cinnamomum cassia (Nees \& T.Nees) J.Presl, needles from Pinus densiflora Siebold et Zuccarini, root from Curcuma longa Linne, and root from Glycyrrhiza glabra Linne were purchased from an herb market in Yeongcheon, Korea. All plant material identities were confirmed by Dr. Ki Hwan Bae of the College of Pharmacy, Chungnam National University (Daejeon, Korea); all voucher specimens have been stored in the herbal bank at the Korea Institute of Oriental Medicine (Daejeon, Korea). Distilled water was filtered through a $0.45-\mu \mathrm{m}$ membrane filter from ADVANTEC (Tokyo, Japan) before analysis. Phosphate-buffered saline PBS) and fetal bovine serum (FBS) were obtained from HyClone (Logan, UT, USA). Dulbecco's modified Eagle's medium (DMEM) was purchased from Lonza (Walkersville, MD, USA). Trypsin/EDTA and penicillin/streptomycin were purchased from Gibco (Grand Island, NY, USA). Anti-phospho-extracellular signal regulated kinase $1 / 2$ (ERK1/2), anti-ERK1/2, anti-phospho-phospholipase C- $\gamma 1$ (PLC $\gamma 1$ ), anti-phospho-p38, anti-p38, anti-phospho-phosphatidylinositol 3-kinase-linked protein kinase $\mathrm{B}$ (Akt), anti-Akt, anti-phospho-c-Jun N-terminal kinase (JNK), anti-JNK, anti-CDK2, anti-CDK4, anti-cyclin D1, anti-cyclin E1, anti-phospho-retinoblastoma protein (Rb), anti-proliferating cell nuclear antigen (PCNA) (PC10), and anti- $\beta$-actin antibodies were purchased from Cell Signaling Technology Inc. (Beverly, MA, USA). Cell Counting Kit-8 (CCK-8) was purchased from Dojindo Molecular Technologies (Rockville, MD, USA). Platelet-derived growth factor (PDGF)-BB was obtained from KOMABIOTECH (Seoul, Korea). All other chemicals were of analytical grade.

\section{Animals}

Male LDL-receptor knockout (Ldlr KO, strain name: LdB6.129S7-Ldlr ${ }^{\text {tm1Her }} /$ J, C57BL/6 background) mice were obtained from The Jackson Laboratory (Bar Harbor, ME, USA) and acclimated for 1 week at a temperature of $25 \pm 2{ }^{\circ} \mathrm{C}$, humidity of $55 \pm 5 \%$ and 12:12 h light-dark cycle. After the mice in the negative control group were given unlimited access to AIN-76A (AIN-76A: casein 200, DL-methionine 3, cornstarch 150, sucrose 500, fiber 50, corn oil 50, AIN mineral mix 35, AIN vitamin mix 10, choline bitartrate $2 \mathrm{~g} / \mathrm{kg}$ ) for 
2 weeks, they were then fed a Western diet for 14 weeks (fat $21 \%$, cholesterol $0.15 \%$, no cholate). The mice in the Kiom-18 group ( $1 \mathrm{~g} / \mathrm{kg}$ ) were fed a Western diet by gavage (oral administration) and were fed at the same time daily. The animal experiments were conducted in accordance with the Korea Institute of Oriental Medicine Care Committee Guidelines and were accepted by the Korea Institute of Oriental Medicine (KIOM) Care and Use Committee. The animals were cared for in accordance with the dictates of the National Animal Welfare Law of Korea.

\section{Preparation of the Kiom-18 extract}

A total of 2470 g Kiom-18, including C. cassia, P. densiflora, C. longa and G. glabra (Individual ratio= $1.3: 1.3$ : 1.4 : 1), was placed in $25 \mathrm{~L}$ of distilled water and then extracted by heating for $3 \mathrm{~h}$ at $115{ }^{\circ} \mathrm{C}$ (Gyeongseo Extractor Cosmos-600, Inchon, Korea). The extract of Kiom-18 was filtered using a standard test sieve of $150 \mu \mathrm{m}$ (Retsch, Haan, Germany), freeze-dried and maintained by desiccators at $4{ }^{\circ} \mathrm{C}$ until use.

\section{Cell culture}

Rat aortic VSMCs, isolated by enzymatic dispersion, were obtained from Biobud Co. (Seongnam-si, Gyeonggi-do, Korea). The isolation of VSMCs has been previously reported [46]. The cells were cultured in DMEM (supplemented with $10 \% \mathrm{FBS}, 100 \mathrm{IU} / \mathrm{mL}$ penicillin, $100 \mu \mathrm{g} / \mathrm{mL}$ streptomycin, $8 \mathrm{mM}$ HEPES, and $2 \mathrm{mM} \mathrm{L}$-glutamine) at $37{ }^{\circ} \mathrm{C}$ in a humidified atmosphere of $95 \%$ air and $5 \%$ $\mathrm{CO}_{2}$. The purity of the cultures was confirmed based on the immunocytochemical localization of $\alpha$-smooth muscle actin. Our experiment used the VSMCs of passages 5-7.

\section{Cell proliferation assay}

Cell proliferation was measured as previously described [47]. VSMCs were examined using colorimetric WST-1 assays (CCK-8; Dojindo Molecular Technologies, Rockville, MD, USA). VSMCs were seeded into 96-well culture plates at $4 \times 10^{4}$ cells $/ \mathrm{mL}$ and then cultured in complete media (DMEM containing $10 \%$ FBS) at $37{ }^{\circ} \mathrm{C}$ for $24 \mathrm{~h}$. After reaching approximately $70 \%$ confluence, VSMCs were incubated with serum-free medium for $24 \mathrm{~h}$, treated with Kiom-18 of various concentrations for another $24 \mathrm{~h}$ in new fresh serum-free medium, and stimulated by PDGF-BB at a concentration of $25 \mathrm{ng} / \mathrm{mL}$. After $24 \mathrm{~h}$, WST-1 reagent (WST-1 premix) was added to the medium, and the cells were incubated for an additional $2 \mathrm{~h}$. The absorbance was measured at $450 \mathrm{~nm}$ using a microplate reader (Packard Instrument Co., Downers Glove, IL, USA). All experimental procedures were performed as per the manufacturer's instructions, and the results are expressed as the percentage of the PDGF-BB-stimulated control.

\section{DNA synthesis}

The measurement of DNA synthesis was monitored using a $\left[{ }^{3} \mathrm{H}\right]$-thymidine incorporation assay, as previously described [48]. The conditions of this assay were as described for the cell proliferation assay. $\left[{ }^{3} \mathrm{H}\right]$-thymidine $(2 \mu \mathrm{Ci} / \mathrm{ml})$ was added $4 \mathrm{~h}$ before harvesting under conditions stimulated by PDGF-BB $25 \mathrm{ng} / \mathrm{ml}$ in serumfree medium. The reaction was stopped by aspirating the medium and subjecting the cultures to sequential washes with PBS containing ethanol/ether $(1: 1, \mathrm{v} / \mathrm{v})$ and $10 \%$ trichloroacetic acid on ice. Acid-insoluble product with $\left[{ }^{3} \mathrm{H}\right]$-thymidine was extracted in $250 \mu \mathrm{l}$ of $0.5 \mathrm{M}$ $\mathrm{NaOH} /$ well, and this solution was combined with $3 \mathrm{ml}$ of scintillation cocktail (Ultimagold, Packard Bioscience, Meriden, CT, USA) and measured using a liquid scintillation counter (LS3801, Beckman, Düsseldorf, Germany).

\section{Cell cycle progression analysis}

The cell cycle progression was measured as previously described [49]. This assay procedure was the same as that described for the cell proliferation assay. After stimulation with PDGF-BB $25 \mathrm{ng} / \mathrm{mL}$ for $24 \mathrm{~h}$, the harvested cells were suspended in $1 \mathrm{~mL}$ of PBS and fixed with $70 \%$ ethanol for $48 \mathrm{~h}$. In the fixed cells, the ethanol was removed, and the pellets were then stained with propidium iodide (PI) solution $(50 \mu \mathrm{g} / \mathrm{mL}$ PI in sample buffer containing $100 \mu \mathrm{g} / \mathrm{mL}$ RNase A). Each sample was incubated at room temperature for $1 \mathrm{~h}$. The PIDNA complex of each cell nucleus was measured using a FACSCalibur flow cytometer (Becton, Dickinson and Co., Franklin Lakes, NJ, USA). The individual nuclear DNA content was determined by the incorporated PI fluorescence intensity. The rate of the cell cycle at the $G_{0} / G_{1}, S$, and $G_{2} / M$ phases was determined by analysis using Modfit LT software (BD, Topsham, ME, USA).

\section{Immunoblotting}

Protein measurement by immunoblotting was performed as previously described [50]. VSMCs were stimulated with PDGF-BB (25 ng/mL) for $5 \mathrm{~min}$ for ERK1/2 and PLC 1 1, $10 \mathrm{~min}$ for JNK and p38, and $15 \mathrm{~min}$ for Akt phosphorylation assays. For the measurements of CDK2, CDK4, cyclin D1, cyclin $\mathrm{E}_{1}, \mathrm{p} 27$ and PCNA expression, and $\mathrm{Rb}$ phosphorylation, VSMCs were stimulated with PDGF-BB (25 ng/mL) for $24 \mathrm{~h}$. Each of the proteins were normalized with $\beta$-actin or the respective total proteins. The band intensities were quantified using Scion Image for Windows (Scion Corp., Frederick, MD, USA).

\section{Immunofluorescence staining}

VSMCs were cultured in 24-well plates that included cover slips at $8 \times 10^{4}$ cells $/ \mathrm{mL}$ and were then stimulated with PDGF-BB $25 \mathrm{ng} / \mathrm{mL}$ for $24 \mathrm{~h}$, after which they were fixed with $2 \%$ paraformaldehyde in PBS for $10 \mathrm{~min}$ and 
then blocked with $5 \%$ bovine serum albumin in PBS for $1 \mathrm{~h}$ at room temperature. The cells were stained with primary antibodies (anti-p27) for $2 \mathrm{~h}$ and then with Alexa Fluor 555-conjugated secondary antibody (Cell Signaling Technology Inc., Beverly, MA, USA). The cells were mounted in PI solution for $10 \mathrm{~min}$ and observed using a fluorescence microscope (TH4-200; Olympus Optical Co. Ltd., Tokyo, Japan).

\section{Atherosclerotic lesion analysis}

The mice were anesthetized with an intraperitoneal injection of ketamine $(50 \mathrm{mg} / \mathrm{kg}$ ) and xylazine $(6.7 \mathrm{mg} / \mathrm{kg})$. After perfusion-fixing with $10 \%$ buffered formalin, the aortic arches were transversely sectioned and stained with hematoxylin and eosin $(\mathrm{H} \& \mathrm{E})$ as previously described [51, 52].

\section{Plasma lipid analysis}

A Hitachi 7080 (Tokyo, Japan) biochemical analyzer was used to measure the serum concentrations of triglyceride (TG), aspartate aminotransferase (AST), alanine aminotransferase (ALT), glucose, total cholesterol (T-C), high-density lipoprotein-cholesterol (HDL-C) and low-density lipoprotein-cholesterol (LDL-C) as previously described $[53,54]$.

\section{Statistical analysis}

The data are expressed as the mean \pm SEM. One-way ANOVA was used for multiple comparisons (GraphPad, San Diego, CA, USA). Dunnett's test was applied if a significant difference was observed among the treated groups. A value of $p<0.05$ was considered statistically significant.

\section{Results}

Effect of Kiom-18 on VSMC proliferation and early signal phosphorylation

To determine the effect of Kiom-18 extract on VSMC proliferation, a colorimetric WST-1 assay was performed. Kiom-18 extract at a concentration of 30 and $50 \mu \mathrm{g} / \mathrm{ml}$ significantly inhibited VSMC proliferation compared with the PDGF-BB-stimulated control (Fig. 1a). To identify the effect of Kiom-18 on VSMC proliferation via early signal transduction pathways, we examined the activation of PLC $\gamma 1$, Akt, p38, ERK1/2, or JNK; however, no difference was observed in the phosphorylation of early signal pathways in the presence of Kiom-18 (Fig. 1b). These results suggest that Kiom-18 has anti-proliferative activity through its downstream effects, although not with regard to early signal transduction pathways, such as the arrest of cell cycle progression, the suppression of cell cycle-related proteins, or the expression of cyclin-dependent kinase inhibitors (CKIs).

\section{Effect of Kiom-18 on DNA synthesis and cell cycle progression}

By $\left[{ }^{3} \mathrm{H}\right]$-thymidine incorporation, Kiom-18 extract at concentrations of $5,10,30$, and $50 \mu \mathrm{g} / \mathrm{ml}$ suppressed by $26.7 \pm 2.5,40.0 \pm 3.4,52.9 \pm 2.2$, and $58.6 \pm 3.7 \%$ compared to the PDGF-BB-stimulated control, respectively (Fig. 2a). The results shown in Fig. $2 \mathrm{~b}$ demonstrate that cell cycle progression was synchronized by the addition of PDGF$\mathrm{BB}$. This result indicates the arrest of the cell cycle at the transition from $G_{0} / G_{1}$ to the $S$ phase after treatment with Kiom-18 extract because the result matched the inhibition effect on DNA synthesis.

\section{Effects of Kiom-18 on cell cycle-related proteins and p27 expression}

To determine the molecular mechanism with regard to the inhibitory effect of Kiom-18 on cell cycle progression, we investigated the inhibitory effect of Kiom-18 extract on CDK2, CDK4, cyclin D1, cyclin E1, PCNA expression and $\mathrm{Rb}$ phosphorylation as positive regulatory proteins. As shown in Fig. 2c, Kiom-18 significantly inhibited the expression of CDK $2 / 4$ and cyclin D1/E1, the $G_{0} / G_{1}$ phase-related proteins. Kiom-18 also suppressed $\mathrm{Rb}$ phosphorylation, which is a major component of the molecular network that modulates the restriction point in the cell cycle progression. Subsequently, the presence of the Kiom-18 extract inhibited PCNA, which is synthesized by a gene that is triggered by hyper-phosphorylated $\mathrm{Rb}$ in the early $\mathrm{G}_{0} / \mathrm{G}_{1}$ and the $\mathrm{S}$ phases (Fig. 2c). We next investigated the effect of Kiom-18 extract on p27 expression. Figure 3a shows that Kiom-18 concentration-dependently increased the expression of $\mathrm{p} 27$, which is the negative regulatory protein of kinase and cyclin, thereby arresting the cell cycle at the $G_{0} / G_{1}$ phase [55].

Additionally, based on the immunofluorescence level of p27 expression, Kiom-18 extract at doses of 30 and $50 \mu \mathrm{g} / \mathrm{ml}$ increased by approximately 2.6- and 2.3-fold, respectively, compared to the PDGF-BB-stimulated control (Fig. $3 \mathrm{~b}$ and $\mathrm{c}$ ). This result, along with the immunoblot results, demonstrates that the cell cycle at the $G_{0} / G_{1}$ phase was suppressed by the presence of the Kiom-18 extract.

\section{Effects of Kiom-18 on LDL-receptor knockout mice}

We used LDLr knockout mice to identify the immediate effect of Kiom-18 extract in an atherosclerosis animal model. The body weight of the mice fed a Western diet for 14 weeks increased; however, that of the group administered Kiom-18 extract significantly decreased (Fig. 4a). As shown in Fig. 4b, Kiom-18 extract also suppressed the fat weight $(\mathrm{g})$, the food efficiency ratio $(100 \times$ weight $(\mathrm{g}) /$ food intake $(\mathrm{g}))$ [56], and neutrophils (\%). Additionally, the serum triglyceride (TG) level was 

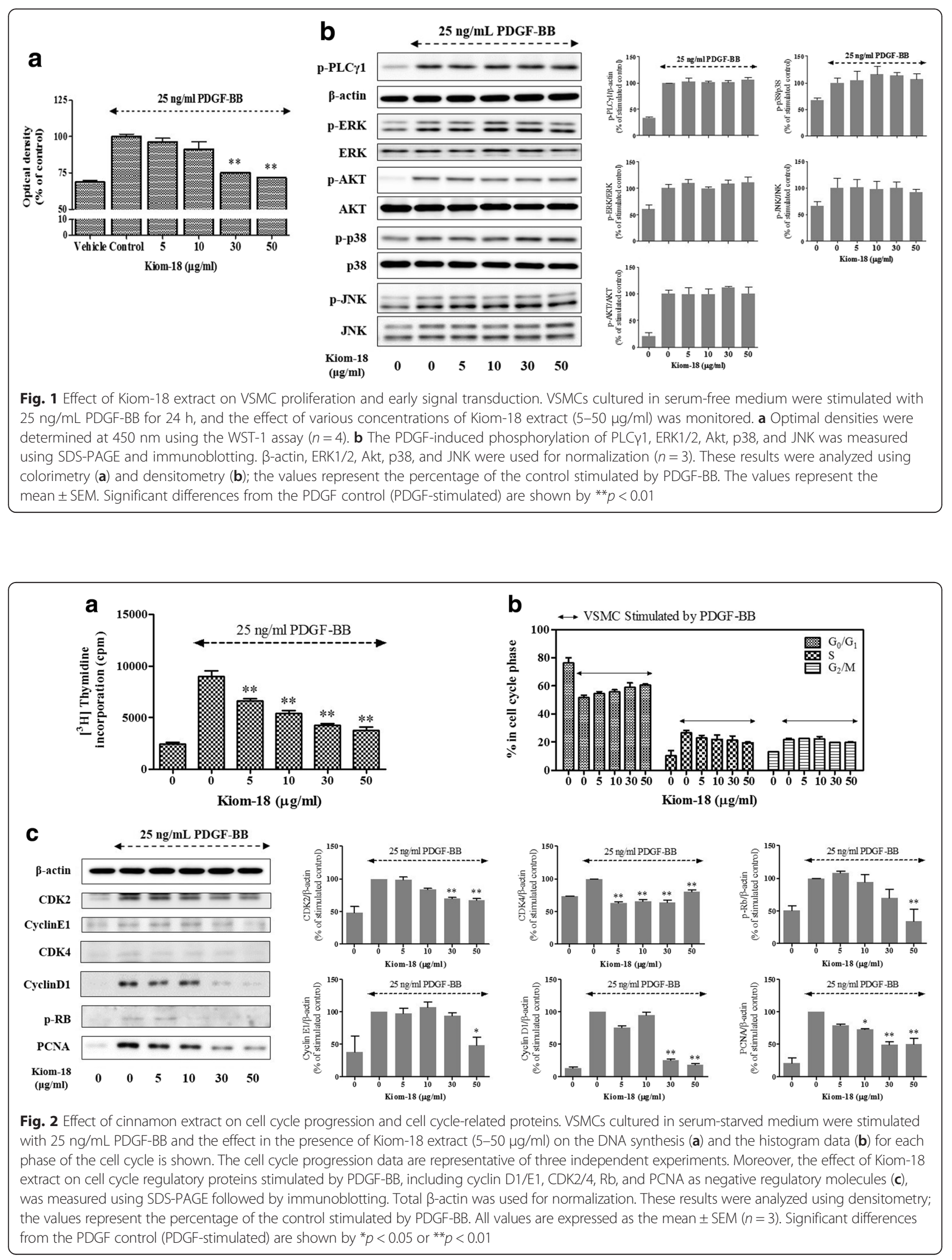


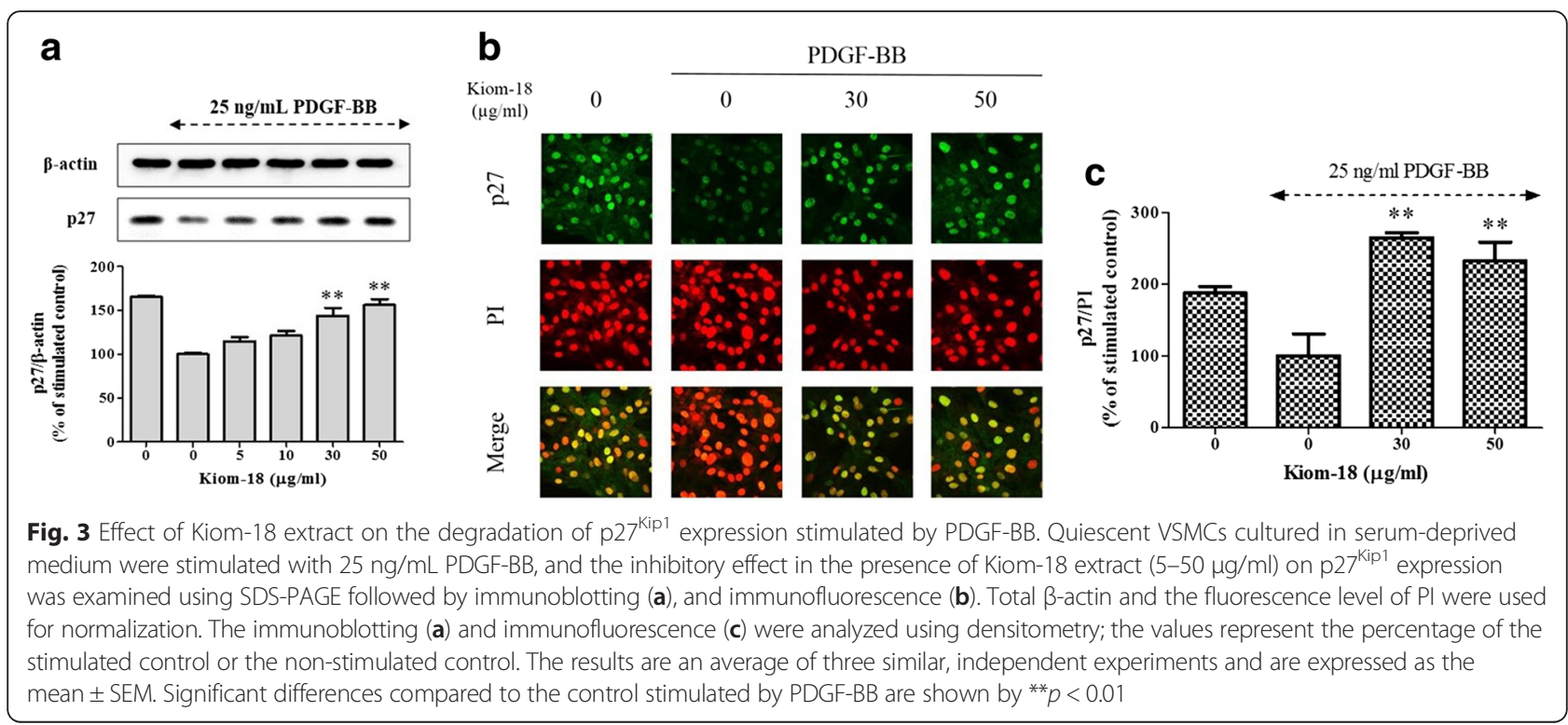

significantly inhibited by Kiom-18 extract compared with the negative controls (Fig. 4c). These results suggest that Kiom-18 extract has a suppressive effect on the atherosclerotic conditions induced by Western dietary consumption, including hyperlipidemia, inflammation, and obesity. In the analysis of the atherosclerotic lesions, Kiom-18 showed an inhibitory effect on neo-intimal formation via VSMC hyperplasia in the aortic arch (Fig. 4d). Moreover, Kiom-18 significantly reduced the neo-intima/media area ratio compared with the control. These findings indicate that the inhibition effect of Kiom-18 is due to the anti-proliferative activity of VSMCs as a result of the events described above.

\section{Discussion}

A large number of functional food products, several of which have shown efficacy, have been developed and marketed [57, 58]. To develop a functional supplement (food) to prevent cardiovascular diseases, such as atherosclerosis, restenosis, stroke and myocardial infarction, we conducted screening tests of traditional medicine stored at the Korea Institute of Oriental Medicine. As a result, Kiom-18, which is a novel composition, was produced as a functional supplement with considerations for safety, efficacy and the supply of raw materials. The Kiom-18 patent has been registered to gain the recognition of the Korean Intellectual Property Office (KIPO) regarding the novelty and efficacy of this composition (registration number: KR1461588).

In this study, we demonstrated that Kiom-18, a novel composition of C. cassia, P. densiflora, C. longa and G. glabra, prevents atherosclerosis through the antiproliferative effect on VSMCs via the regulation of cell cycle-related proteins such as CDK2, CDK4, cyclin D1, cyclin E1, Rb, and PCNA. These effects of the Kiom-18 extract were identified as preventive by increasing p27 expression, which has been recognized as a negative regulator of cyclins and protein kinase, and in arresting the cell cycle at the $G_{0} / G_{1}$ phase $[13,55]$. Although it will require further study, including in clinical trials, Kiom-18 extract may be used as a functional food supplement to manage atherosclerosis.

Atherosclerotic lesion formation is caused by VSMC proliferation stimulated by cytokines and growth factors secreted via endothelial cell dysfunction including the inflammatory process $[59,60]$. Ultimately, this pathway is modulated by the transcriptional process of cell cycleregulatory proteins and genes promoting the proliferation of VSMCs [61]. Hence, the inhibition of VSMC proliferation is considered an important target for the treatment and prevention of atherosclerosis.

In the present study, we confirmed the anti-proliferative activity of Kiom-18 extract on VSMCs, which significantly inhibited PDGF-BB-stimulated VSMC proliferation (Fig. 1a). VSMC proliferation was primarily regulated by the phosphorylation of early signals, such as AKT, ERK1/ 2, JNK, p38, and PLC 1 , stimulated by PDGF-BB $[49,62]$. However, in this study, Kiom-18 extract had no direct effect on the phosphorylation of early signals, suggesting that the anti-proliferative activity of Kiom-18 extract was not due to its effect on early signaling pathways (Fig. 1b). We next examined the effect of Kiom-18 in the downstream signal transduction of early signal phosphorylation, including cell cycle progression, to determine the target of its anti-proliferative effect [63]. Cell cycle progression in VSMC proliferation is modulated by regulatory proteins, such as cyclins, CDKs, pRb, and PCNA, which are considered important targets for the inhibition of proliferation 


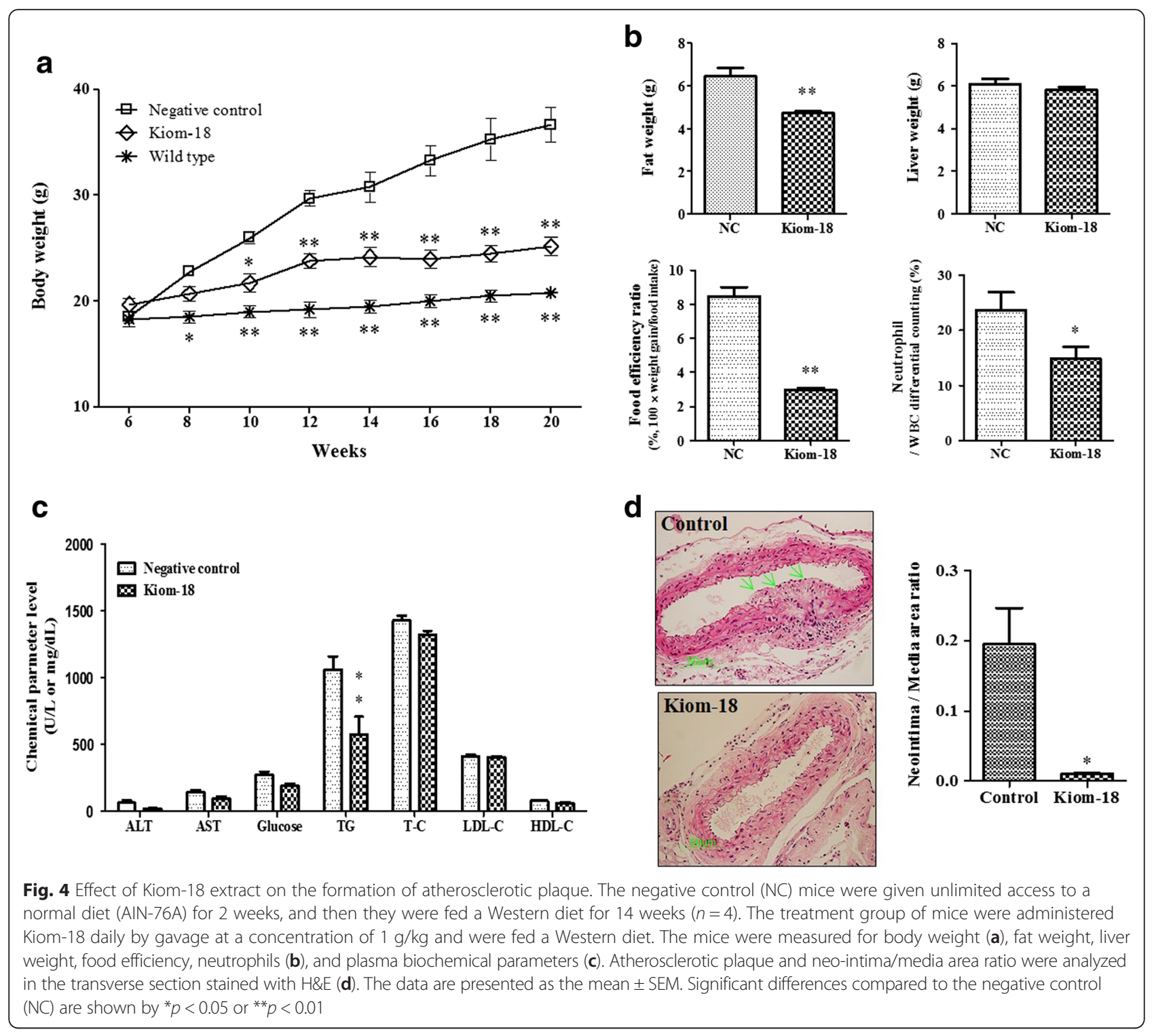

$[11,61,64,65]$. Kiom-18 extract concentrationdependently suppressed DNA synthesis via cell cycle arrest at the $G_{0} / G_{1}$ phase (Fig. $2 a$ and b). Among the sequential phases of the cell cycle, the transition from the $\mathrm{G}_{0} / \mathrm{G}_{1}$ phase to the $\mathrm{S}$ phase was mediated by $\mathrm{CDK} 2 /$ cyclin E1 and CDK4/cyclin D1 complexes [66]; as a result, this transition led to the phosphorylation of Rb. The Kiom-18 extract, according to the findings regarding cell cycle progression, significantly suppressed the phosphorylation of $\mathrm{Rb}$ by inhibiting the CDK2/cyclin E1 and CDK4/cyclin D1 complexes, resulting in the decreased expression of PCNA (Fig. 2c), which is synthesized as a product of the phosphorylated Rb-mediated gene in the cell cycle transition of $G_{0} / G_{1}$ to $S$ phase [67]. This transition at $G_{0} / G_{1}$ to $S$ phase was modulated by the CKIs such as INK4 and the Cip/Kip family [11]. Among the Cip/Kip family, the Kiom-18 extract increased the expression of $\mathrm{p} 27^{\mathrm{Kip} 1}$ in the immunoblotting assay (Fig. 3a), as it is a negative regulator associated with protein kinase and cyclin of the cell cycle at the $G_{0} / G_{1}$ phase [55]. Additionally, p2 $7^{\text {Kip } 1}$ expression was identified by an increase in the fluorescence level while in the presence of the Kiom-18 extract (Fig. 3b), which was significantly upregulated in correlation with the immunoblotting results (Fig. 3c). These results indicate that the anti-proliferative effect of Kiom-18 extract is associated with the arrest of the cell cycle transition of $\mathrm{G}_{0} /$ $\mathrm{G}_{1}$ to $\mathrm{S}$ phase via the upregulation of $\mathrm{p} 27^{\mathrm{Kip} 1}$ expression. This anti-proliferative activity of Kiom-18 extract is caused by the modulation of cell cycle-related proteins rather than by early signal transduction pathways $[48,68]$.

The enhanced proliferation of VSMCs contributed to the formation of atherosclerotic plaque [69], and 
although the KIOM-18 extract was used in a relatively high concentration in LDLr knockout mice, the Kiom-18 extract suppressed the development of atherosclerotic plaque in an animal model (Fig. 4). In previous studies using $\mathrm{p} 27^{\mathrm{Kip} 1}$ or ApoE-deficient mice, p2 $7^{\text {Kip1 }}$ expression was reported to be an important factor in preventing atherosclerosis [70, 71]. Even if p27 ${ }^{\text {Kip1 }}$ expression was not directly identified in animal models, based on previous reports, the inhibitory effect of Kiom-18 on the formation of atherosclerotic plaque could be expected by the upregulation of $\mathrm{p} 27^{\mathrm{Kip} 1}$ expression. Moreover, because the development of atherosclerotic plaque is caused by the consumption of a high-fat diet, this animal model demonstrated increases in body weight, fat weight, liver weight, food efficiency, neutrophil count, and blood chemical parameters. The Kiom-18 extract significantly inhibited the body weight (Fig. 4a), fat weight, food efficiency ratio (\%), neutrophils (by \% of WBC differential counting) (Fig. 4b), and TG level (Fig. 4c). These results indicate that Kiom-18 extract has preventive effects in a high-fat-induced atherosclerosis animal model.

\section{Conclusion}

Our results demonstrate that Kiom-18 extract inhibited the formation of atherosclerotic plaque by inhibiting VSMC proliferation through a $G_{0} / G_{1}$ arrest, which upregulated the $\mathrm{p} 27^{\mathrm{Kip} 1}$ expression. Therefore, we cautiously anticipate that Kiom-18 extract may be used as a functional food supplement or as a preventive agent to manage atherosclerosis.

\begin{abstract}
Abbreviations
Akt, phosphatidylinositol 3-kinase-linked protein kinase; C. cassia, Cinnamomum cassia; C. longa, Curcuma longa; CCK-8, cell counting Kit-8; CDK, cyclin-dependent kinase; CKl, cyclin-dependent kinase inhibitor; DMEM, Dulbecco's modified Eagle's medium; ERK, extracellular signal regulated kinase 1/2; FBS, fetal bovine serum; G. glabra, Glycyrrhiza glabra; JNK, c-Jun N-terminal kinase; LDL, low-density lipoprotein; P. densiflora, Pinus densiflora; PBS, phosphate-buffered saline; PCNA, proliferating cell nuclear antigen; PDGF-BB, platelet-derived growth factor; PLCY1, phospholipase C- $\gamma 1$; Rb, retinoblastoma protein; VSMC, vascular smooth muscle cell
\end{abstract}

\section{Acknowledgements}

The authors would like to thank all of the colleagues who contributed to this study.

\section{Funding}

This work was supported by a grant (K16281) awarded to the KIOM from the Ministry of Science, ICT and Future Planning (MISP), Republic of Korea.

\section{Availability of data and materials}

The datasets supporting the conclusions of this article are included within this article.

\section{Authors' contributions}

$J \mathrm{JL}$ and JYM participated in the design of the study; JJL, JHL, WKC and JHH carried out the experiments, analyzed the data, and wrote the paper.

All authors read and approved the final manuscript.

\section{Competing interests}

The authors declare that they have no competing interests.

\section{Consent for publication}

Not applicable.

\section{Ethics approval and consent to participate}

All animal procedures were approved by the Korea Institute of Oriental Medicine (KIOM) Care and Use Committee and were performed according to the Korea Institute of Oriental Medicine Care Committee Guidelines followed the dictates of the National Animal Welfare Law of Korea.

\section{Author details}

${ }^{1}$ Korean Medicine (KM) Application Center, Korea Institute of Oriental Medicine, Daegu 701-300, Republic of Korea. ${ }^{2}$ Department of Pharmacology, Chungnam National University College of Pharmacy, Daejeon 305-764, Republic of Korea.

Received: 23 January 2016 Accepted: 15 July 2016

Published online: 28 July 2016

\section{References}

1. Faxon DP, Creager MA, Smith Jr SC, Pasternak RC, Olin JW, Bettmann MA, Criqui MH, Milani RV, Loscalzo J, Kaufman JA, et al. Atherosclerotic Vascular Disease Conference: Executive summary: Atherosclerotic Vascular Disease Conference proceeding for healthcare professionals from a special writing group of the American Heart Association. Circulation. 2004;109(21):2595-604.

2. Ross R. The pathogenesis of atherosclerosis: a perspective for the 1990s. Nature. 1993;362(6423):801-9.

3. Kanamasa K, Inoue Y, Otani N, Naito N, Morii H, Ikeda A, Taniguchi M, Ishida N, Hayashi T, Ishikawa K. tPA via infusion catheters followed by continuous IV infusion for 3 days prevents intimal hyperplasia after balloon injury. Angiology. 2001:52(12):819-25.

4. Martin KA, Rzucidlo EM, Merenick BL, Fingar DC, Brown DJ, Wagner RJ, Powell RJ. The mTOR/p70 S6K1 pathway regulates vascular smooth muscle cell differentiation. Am J Physiol Cell Physiol. 2004;286(3):C507-17.

5. Mason DP, Kenagy RD, Hasenstab D, Bowen-Pope DF, Seifert RA, Coats S, Hawkins SM, Clowes AW. Matrix metalloproteinase-9 overexpression enhances vascular smooth muscle cell migration and alters remodeling in the injured rat carotid artery. Circ Res. 1999:85(12):1179-85.

6. Morgan DO. Principles of CDK regulation. Nature. 1995;374(6518):131-4.

7. Zhan Y, Kim S, Izumi Y, Izumiya Y, Nakao T, Miyazaki H, Iwao H. Role of JNK, p38, and ERK in platelet-derived growth factor-induced vascular proliferation, migration, and gene expression. Arterioscler Thromb Vasc Biol. 2003;23(5):795-801.

8. Collins K, Jacks T, Pavletich NP. The cell cycle and cancer. Proc Natl Acad Sci U S A. 1997;94(7):2776-8.

9. Jacks T, Weinberg RA. Cell-cycle control and its watchman. Nature. 1996; 381(6584):643-4.

10. Sherr CJ. Mammalian G1 cyclins and cell cycle progression. Proc Assoc Am Physicians. 1995;107(2):181-6.

11. Sherr CJ, Roberts JM. CDK inhibitors: positive and negative regulators of G1-phase progression. Genes Dev. 1999;13(12):1501-12.

12. Braun-Dullaeus RC, Mann MJ, Seay U, Zhang L, von Der Leyen HE, Morris RE, Dzau VJ. Cell cycle protein expression in vascular smooth muscle cells in vitro and in vivo is regulated through phosphatidylinositol 3-kinase and mammalian target of rapamycin. Arterioscler Thromb Vasc Biol. 2001;21(7):1152-8

13. Fouty BW, Rodman DM. Mevastatin can cause G1 arrest and induce apoptosis in pulmonary artery smooth muscle cells through a p27Kip1-independent pathway. Circ Res. 2003:92(5):501-9.

14. Tanner FC, Boehm M, Akyurek LM, San H, Yang ZY, Tashiro J, Nabel GJ, Nabel EG. Differential effects of the cyclin-dependent kinase inhibitors p27(Kip1), p21(Cip1), and p16(Ink4) on vascular smooth muscle cell proliferation. Circulation. 2000;101(17):2022-5.

15. Yang ZY, Simari RD, Perkins ND, San H, Gordon D, Nabel GJ, Nabel EG. Role of the p21 cyclin-dependent kinase inhibitor in limiting intimal cell proliferation in response to arterial injury. Proc Natl Acad Sci U S A. 1996;93(15):7905-10. 
16. Chang JS, Wang KC, Shieh DE, Hsu FF, Chiang LC. Ge-Gen-Tang has antiviral activity against human respiratory syncytial virus in human respiratory tract cell lines. J Ethnopharmacol. 2012;139(1):305-10.

17. Fujimoto N, Tajima S. Extensive fixed drug eruption due to the Japanese herbal drug "kakkon-to". Br J Dermatol. 2003;149(6):1303-5.

18. Kurokawa M, Tsurita M, Brown J, Fukuda Y, Shiraki K. Effect of interleukin-12 level augmented by Kakkon-to, a herbal medicine, on the early stage of influenza infection in mice. Antiviral Res. 2002;56(2):183-8.

19. Li G, Qi W, Xiong K. Clinical observation on 51 patients of acute myocardial infarction treated with thrombolytic therapy combined with Chinese herbal medicine. Zhongguo Zhong xi yi jie he za zhi Zhongguo Zhongxiyi jiehe zazhi. 1999;19(8):461-2.

20. He Z, Wu Y, Jiang MX, Cheng RQ, Shen R. Observation by color Doppler ultrasound on endothelium-dependent dilation of congestive heart failure treated with Kanli Decoction. Zhong Xi Yi Jie He Xue Bao. 2004;2(4):268-70.

21. Liu J, Peter K, Shi D, Zhang L, Dong G, Zhang D, Breiteneder H, Jakowitsch J, Ma Y. Traditional formula, modern application: chinese medicine formula sini tang improves early ventricular remodeling and cardiac function after myocardial infarction in rats. Evid Based Complement Alternat Med. 2014;2014:141938.

22. Kim KY, Chung HJ. Flavor compounds of pine sprout tea and pine needle tea. J Agric Food Chem. 2000;48(4):1269-72.

23. Kim H, Song MJ, Potter D. Medicinal efficacy of plants utilized as temple food in traditional Korean Buddhism. J Ethnopharmacol. 2006;104(1-2):32-46.

24. Ghorbani Z, Hekmatdoost A, Mirmiran P. Anti-hyperglycemic and insulin sensitizer effects of turmeric and its principle constituent curcumin. Int J Endocrinol Metab. 2014;12(4):e18081.

25. Sung Roh J, Lee H, Woo S, Yoon M, Kim J, Dong Park S, Shik Shin S, Yoon M: Herbal composition Gambigyeongsinhwan (4) from curcuma longa, Alnus japonica, and massa Medicata Fermentata inhibits lipid accumulation in 3T3-L1 cells and regulates obesity in Otsuka long-Evans Tokushima fatty rats. J Ethnopharmacol. 2015;171:287-94.

26. Russo M, Serra D, Suraci F, Di Sanzo R, Fuda S, Postorino S. The potential of e-nose aroma profiling for identifying the geographical origin of licorice (Glycyrrhiza glabra L.) roots. Food Chem. 2014;165:467-74.

27. Asl MN, Hosseinzadeh H. Review of pharmacological effects of Glycyrrhiza sp. and its bioactive compounds. Phytother Res. 2008;22(6):709-24.

28. Huh JE, Kim SJ, Kang JW, Nam DW, Choi DY, Park DS, Lee JD. The standardized $\mathrm{BHH} 10$ extract, a combination of Astragalus membranaceus, Cinnamomum cassia, and Phellodendron amurense, reverses bone mass and metabolism in a rat model of postmenopausal osteoporosis. Phytother Res. 2015;29(1):30-9

29. Kim EC, Kim HJ, Kim TJ. Water extract of Cinnamomum cassia suppresses angiogenesis through inhibition of VEGF receptor 2 phosphorylation. Biosci Biotechnol Biochem. 2015:79(4):1-8.

30. Muhammad JS, Zaidi SF, Shaharyar S, Refaat A, Usmanghani K, Saiki I, Sugiyama T. Anti-inflammatory Effect of Cinnamaldehyde in Helicobacter pylori Induced Gastric Inflammation. Biol Pharm Bull. 2015;38(1):109-15.

31. Yan YM, Fang P, Yang MT, Li N, Lu Q, Cheng YX. Anti-diabetic nephropathy compounds from Cinnamomum cassia. J Ethnopharmacol. 2015;165:141-7.

32. Li J, Teng Y, Liu S, Wang Z, Chen Y, Zhang Y, Xi S, Xu S, Wang R, Zou X. Cinnamaldehyde affects the biological behavior of human colorectal cancer cells and induces apoptosis via inhibition of the PI3K/Akt signaling pathway. Oncol Rep. 2016;35(3):1501-10.

33. Hwang YJ, Wi HR, Kim HR, Park KW, Hwang KA. Pinus densiflora Sieb. et Zucc. alleviates lipogenesis and oxidative stress during oleic acid-induced steatosis in HepG2 cells. Nutrients. 2014;6(7):2956-72.

34. Jo JR, Park JS, Park YK, Chae YZ, Lee GH, Park GY, Jang BC. Pinus densiflora leaf essential oil induces apoptosis via ROS generation and activation of caspases in YD-8 human oral cancer cells. Int J Oncol. 2012;40(4):1238-45.

35. Patra JK, Kim SH, Hwang H, Choi JW, Baek KH. Volatile compounds and antioxidant capacity of the bio-oil obtained by pyrolysis of Japanese red pine (pinus densiflora siebold and zucc.). Molecules. 2015;20(3):3986-4006.

36. Issuriya A, Kumarnsit E, Wattanapiromsakul C, Vongvatcharanon U. Histological studies of neuroprotective effects of Curcuma longa Linn. on neuronal loss induced by dexamethasone treatment in the rat hippocampus. Acta Histochem. 2014;116(8):1443-53.

37. Lekshmi PC, Arimboor R, Nisha VM, Menon AN, Raghu KG. In vitro antidiabetic and inhibitory potential of turmeric (Curcuma longa L) rhizome against cellular and LDL oxidation and angiotensin converting enzyme. J Food Sci Technol. 2014;51(12):3910-7.
38. Kalani K, Chaturvedi V, Alam S, Khan F, Srivastava SK. Anti-tubercular agents from Glycyrrhiza glabra. Curr Top Med Chem. 2015;15(11):1043-9.

39. Rasool M, lqbal J, Malik A, Ramzan HS, Qureshi MS, Asif M, Qazi MH, Kamal MA, Chaudhary AG, Al-Qahtani MH, et al. Hepatoprotective effects of Silybum marianum (Silymarin) and Glycyrrhiza glabra (Glycyrrhizin) in combination: a possible synergy. Evid Based Complement Alternat Med. 2014;2014:641597.

40. Belinky PA, Aviram M, Fuhrman B, Rosenblat M, Vaya J. The antioxidative effects of the isoflavan glabridin on endogenous constituents of LDL during its oxidation. Atherosclerosis. 1998;137(1):49-61.

41. Chang YL, Chen CL, Kuo CL, Chen BC, You JS. Glycyrrhetinic acid inhibits ICAM-1 expression via blocking JNK and NF-kappaB pathways in TNF-alphaactivated endothelial cells. Acta Pharmacol Sin. 2010;31(5):546-53.

42. Quiles JL, Mesa MD, Ramirez-Tortosa CL, Aguilera CM, Battino M, Gil A, Ramirez-Tortosa MC. Curcuma longa extract supplementation reduces oxidative stress and attenuates aortic fatty streak development in rabbits. Arterioscler Thromb Vasc Biol. 2002;22(7):1225-31.

43. Shin HS, Han JM, Kim HG, Choi MK, Son CG, Yoo HR, Jo HK, Seol IC. Antiatherosclerosis and hyperlipidemia effects of herbal mixture, Artemisia iwayomogi Kitamura and Curcuma longa Linne, in apolipoprotein Edeficient mice. J Ethnopharmacol. 2014;153(1):142-50.

44. Vaya J, Belinky PA, Aviram M. Antioxidant constituents from licorice roots: isolation, structure elucidation and antioxidative capacity toward LDL oxidation. Free Radic Biol Med. 1997;23(2):302-13.

45. Singh V, Rana M, Jain M, Singh N, Naqvi A, Malasoni R, Dwivedi AK, Dikshit M, Barthwal MK. Curcuma oil attenuates accelerated atherosclerosis and macrophage foam-cell formation by modulating genes involved in plaque stability, lipid homeostasis and inflammation. Br J Nutr. 2015;113(1):100-13.

46. Chamley JH, Campbell GR, McConnell JD, Groschel-Stewart U. Comparison of vascular smooth muscle cells from adult human, monkey and rabbit in primary culture and in subculture. Cell Tissue Res. 1977;177:503-22.

47. Lee JJ, Yu JY, Zhang WY, Kim TJ, Lim Y, Kwon JS, Kim DW, Myung CS, Yun YP. Inhibitory effect of fenofibrate on neointima hyperplasia via $G(0) / G(1)$ arrest of cell proliferation. Eur J Pharmacol. 2011;650(1):342-9.

48. Lee JJ, Yi H, Kim IS, Kim Y, Nhiem NX, Kim YH, Myung CS. (2S)-naringenin from Typha angustata inhibits vascular smooth muscle cell proliferation via a G0/G1 arrest. J Ethnopharmacol. 2012;139(3):873-8.

49. Kim TJ, Lim Y, Kim DW, Kwon JS, Son JH, Jin YR, Son DJ, Jung JC, Avery MA, Hong JT, et al. Epothilone D, a microtubule-stabilizing compound, inhibits neointimal hyperplasia after rat carotid artery injury by cell cycle arrest via regulation of G1-checkpoint proteins. Vascul Pharmacol. 2007;47(4):229-37.

50. Kwon H, Lee JJ, Lee JH, Cho WK, Gu MJ, Lee KJ, Ma JY. Cinnamon and its components suppress vascular smooth muscle cell proliferation by up-regulating cyclin-dependent kinase inhibitors. Am J Chin Med. 2015;43(4):621-36.

51. Sanz-Gonzalez SM, Barquin L, Garcia-Cao I, Roque M, Gonzalez JM, Fuster JJ, Castells MT, Flores JM, Serrano M, Andres V. Increased p53 gene dosage reduces neointimal thickening induced by mechanical injury but has no effect on native atherosclerosis. Cardiovasc Res. 2007;75(4):803-12.

52. Sanz-Gonzalez SM, Melero-Fernandez de Mera R, Malek NP, Andres V. Atheroma development in apolipoprotein E-null mice is not regulated by phosphorylation of p27(Kip1) on threonine 187. J Cell Biochem. 2006:97(4):735-43.

53. Fukuyama N, Homma K, Wakana N, Kudo K, Suyama A, Ohazama H, Tsuji C, Ishiwata K, Eguchi Y, Nakazawa H, et al. Validation of the Friedewald equation for evaluation of plasma LDL-cholesterol. J Clin Biochem Nutr. 2008:43(1):1-5.

54. Zhou X, Hansson GK. Effect of sex and age on serum biochemical reference ranges in C57BL/6J mice. Comp Med. 2004;54(2):176-8.

55. Abukhdeir AM, Park BH. P21 and p27: roles in carcinogenesis and drug resistance. Expert Rev Mol Med. 2008;10:e19.

56. Lopez-Varela S, Sanchez-Muniz FJ, Cuesta C. Decreased food efficiency ratio, growth retardation and changes in liver fatty acid composition in rats consuming thermally oxidized and polymerized sunflower oil used for frying. Food Chem Toxicol. 1995;33(3):181-9.

57. Davila MA, Sangronis E, Granito M. Germinated or fermented legumes: food or ingredients of functional food. Arch Latinoam Nutr. 2003;53(4):348-54.

58. Wepner U. Pharmacologic effect of foods of plant origin. "Functional food" fresh from the market. MMW Fortschr Med. 2003;145(43):4-5.

59. Ross R. Mechanisms of atherosclerosis-a review. Adv Nephrol Necker Hosp. 1990;19:79-86. 
60. Ross R. Atherosclerosis-an inflammatory disease. N Engl J Med. 1999;340(2):115-26.

61. Dzau VJ, Braun-Dullaeus RC, Sedding DG. Vascular proliferation and atherosclerosis: new perspectives and therapeutic strategies. Nat Med. 2002;8(11):1249-56.

62. Sachinidis A, Locher R, Vetter W, Tatje D, Hoppe J. Different effects of platelet-derived growth factor isoforms on rat vascular smooth muscle cells. J Biol Chem. 1990;265(18):10238-43.

63. Higaki M, Shimokado K. Phosphatidylinositol 3-kinase is required for growth factor-induced amino acid uptake by vascular smooth muscle cells. Arterioscler Thromb Vasc Biol. 1999;19(9):2127-32.

64. Braun-Dullaeus RC, Mann MJ, Sedding DG, Sherwood SW, von der Leyen HE, Dzau VJ. Cell cycle-dependent regulation of smooth muscle cell activation. Arterioscler Thromb Vasc Biol. 2004;24(5):845-50.

65. Sherr CJ. Cancer cell cycles. Science. 1996;274(5293):1672-7.

66. Sherr CJ. G1 phase progression: cycling on cue. Cell. 1994;79(4):551-5.

67. Tomita H, Osanai T, Toki T, Maeda N, Murakami R, Chen Z, Yamabe H, Osawa H, Yasujima M, Okumura K. Roxithromycin is an inhibitor of human coronary artery smooth muscle cells proliferation: a potential ability to prevent coronary heart disease. Atherosclerosis. 2005;182(1):87-95

68. Findeisen HM, Gizard F, Zhao Y, Qing H, Heywood EB, Jones KL, Cohn D, Bruemmer D. Epigenetic regulation of vascular smooth muscle cell proliferation and neointima formation by histone deacetylase inhibition. Arterioscler Thromb Vasc Biol. 2011;31(4):851-60.

69. Orr AW, Hastings NE, Blackman BR, Wamhoff BR. Complex regulation and function of the inflammatory smooth muscle cell phenotype in atherosclerosis. J Vasc Res. 2010;47(2):168-80.

70. Diez-Juan A, Andres V. The growth suppressor p27(Kip1) protects against diet-induced atherosclerosis. FASEB J. 2001;15(11):1989-95.

71. Shahzad K, Thati M, Wang H, Kashif M, Wolter J, Ranjan S, He T, Zhou Q, Blessing $\mathrm{E}$, Bierhaus $\mathrm{A}$, et al. Minocycline reduces plaque size in diet induced atherosclerosis via p27(Kip1). Atherosclerosis. 2011;219(1):74-83.

\section{Submit your next manuscript to BioMed Central and we will help you at every step:}

- We accept pre-submission inquiries

- Our selector tool helps you to find the most relevant journal

- We provide round the clock customer support

- Convenient online submission

- Thorough peer review

- Inclusion in PubMed and all major indexing services

- Maximum visibility for your research

Submit your manuscript at www.biomedcentral.com/submit 